\title{
Evaluating Student Satisfaction with Blended Learning in a Gender-Segregated Environment
}

\author{
Mahmoud Abou Naaj, Mirna Nachouki, and Ahmed Ankit \\ Ajman University of Science \& Technology, \\ Ajman, United Arab Emirates
}

abounaaj@ajman.ac.ae; mirna@ajman.ac.ae; ankit@ajman.ac.ae

\section{Executive Summary}

Blended learning combines multiple delivery media that are designed to complement each other and promote learning and application-learned behavior (Smith \& Dillon, 1999). This article reports on a study conducted in the College of Information Technology to evaluate levels of student' satisfaction with blended learning. The particular blend of learning modalities used at the college combines an equal balance of traditional face-to-face and videoconference learning, complemented with the use of a learning management system (Moodle).

Recently, discussions of blended learning have begun to examine the benefits derived from learning situations characterized by face-to-face education and mixed modalities of instruction. Regardless of comparisons made by researchers and developers, those studying blended learning have agreed that student satisfaction is a baseline requirement for successful implementation.

Student satisfaction is considered an important factor in measuring the quality of blended learning. It results from a combination of factors. In this study a model is proposed by the aggregation of these factors into five groups: instructor, technology, class management, interaction, and instruction. The purpose of this study is to develop and validate an instrument that can be used to measure perceived student satisfaction with blended learning and explore whether satisfaction differs according to gender. The results indicate that the Student Satisfaction Survey Forms (SSSF) used were a valid measure of student satisfaction. They also show that students were satisfied with all components, although the level of satisfaction varied according to gender.

Keywords: Blended learning, Videoconferencing, Student satisfaction, Gender segregation.

\section{Introduction}

\section{Geographical and Cultural Context}

The United Arab Emirates (UAE) consists of the seven small emirates of Abu Dhabi, Dubai,

Material published as part of this publication, either on-line or in print, is copyrighted by the Informing Science Institute. Permission to make digital or paper copy of part or all of these works for personal or classroom use is granted without fee provided that the copies are not made or distributed for profit or commercial advantage AND that copies 1) bear this notice in full and 2) give the full citation on the first page. It is permissible to abstract these works so long as credit is given. To copy in all other cases or to republish or to post on a server or to redistribute to lists requires specific permission and payment of a fee. Contact Publisher@,InformingScience.org to request redistribution permission.
Sharjah, Ras Al-Khaimah, Ajman, Umm Al-Qaiwain, and Fujairah, which were united as a federal state on 2 December 1971. Before the establishment of the oil economy in the early 1960s, two main orientations shaped traditional Emirati culture: the nomadic desert-oriented Bedouins with small oasis farming within the broader context of the desert economy and culture, and the seaoriented culture that revolved around 
pearling and sea trading. These subcultures were economically, politically, and socially interdependent, creating a common culture and social identity. The UAE shares significant aspect of its culture with neighboring Arab Gulf countries and the larger Arab culture. Gulf inhabitants generally concur that gender segregation is sanctioned by the Holy Qur'an, related to the principle of hijab in its extended symbolic sense of modesty and privacy beyond its more common meaning of veiling and covering (Weber, 2010).

Modern economic roles and social status reflect both change and continuity for women. Schools and universities are segregated, and levels of enrollment of girls and their performance are impressive. In the Gulf countries higher education, female students outnumber males. According to Al-Yousif (2009) 60\% of all university students in the six states of the Gulf are women. In the UAE the ratio is almost two to one. On average, 70.8 percent of UAE national students enrolled in higher education are women (Women in the UAE, 2012). UAE society places a high value on those roles. Conservative cultural attitudes lead women to seek jobs that do not involve mixing with men or commuting far from home. Subsequently, most women are employed in education, health, and the Civil Service (Culture of United Arab Emirates, n.d.). Besides the traditional fields of education and health, there are many women graduates working in various disciplines such as engineering, science, media and communications, computer technology, law, commerce, and the oil industry (Women in the UAE, 2012). Official statements affirm that men and women have equal rights and opportunities to advance themselves and the nation (UAE Constitution, n.d.; Women in the United Arab Emirates: A Portrait of Progress, 2008), yet patriarchy as a generalized ideology is still visible in social life (Culture of United Arab Emirates, n.d.).

The UAE has established an excellent and diversified system of higher education in a very short period of time. Nationals can attend government institutions free of charge, and a wide range of private institutions, many with international accreditation, supplement the public sector. The country now has one of the highest application participation rates in the world. Ninety-five per cent of all females and 80 per cent of all males who are enrolled in the final year of secondary school apply for admission to a higher education institution or to study abroad (UAE, The official Website, 2012).There are 72 public and private institutions of higher education in the country with over a hundred thousand students (Ministry of Higher Education, 2011).

The public universities in UAE offer segregated classes so that women who prefer such type of education have the choice to achieve their goals. It is not always easy to sustain such option economically as duplication is costly. It is, however, not possible to discuss education gender segregation without understanding the social convictions of the UAE society, a modern society that adheres to the traditional values. It is, however, worth noting that there are a number of gender co-education private institutions in which some UAE women complete their studies. In the UAE about 75 percent of students registered in accredited higher education institution are in gendersegregated institutions (Ministry of Higher Education, 2011).

Ajman University of Science and Technology (AUST) was founded in 1988 as the first private institution of higher education in United Arab Emirates and Gulf Cooperation Council states, and since its foundation has operated a system involving gender segregation. In all programs, which comprise 26 accredited undergraduate programs and six accredited master's programs, two sections are created for each class taught - one for male and the other for female students. Traditionally, the instructor responsible has taught both sections, and, therefore, the same lecture has been delivered twice. However, as a private university, AUST faces many of the same challenges as other business organizations - it must do more and better with less resources. The university has, therefore, explored ways to increase efficiency in its teaching and learning systems. 


\section{Blended-Learning}

In recent years, the rapid development of information and communication technology has facilitated a convergence between face-to-face and technology-mediated learning environments. Won Kim (2007) has defined a variety of learning methods as follows.

1. Formal, class-scheduled and course-scheduled, physical class learning (traditional learning).

2. Formal, course-scheduled, no physical class but face-to-face interaction-based learning. Examples of this type of learning include dissertation research, independent study, and industry co-op courses offered by universities.

3. Formal, class-scheduled and course-scheduled, e-learning. This is distance learning and is the e-learning equivalent of traditional learning. Students do not need to be physically present in the classroom but can participate from remote locations. However, the class is offered on a fixed schedule, as with a traditional class.

4. Formal, course-scheduled e-learning. This type of e-learning has been adopted by universities, corporations, and government departments.

5. Informal, class-scheduled and course-scheduled, physical class learning: traditional learning corresponding to auditing where students do not receive a formal credit.

6. Informal, unscheduled e-learning. This type of e-learning is adopted by those who would like to investigate a topic on their own, from anywhere at any time.

The blended learning approach has been selected, as a potential solution to reduce duplication, in particular situations where the number of students is small in one or both class sections. Blended learning, for the purposes of this article, is defined as "a combination of face-to-face and videoconference learning, complemented with the use of Moodle as a learning management system." There is one important qualifier to this definition in that at least one of the learning types must be a physical class-based type, regardless of level of formality, or there is a course schedule or faceto-face interaction outside the physical classroom. At the same time, at least one other learning type must be of the e-learning variety (likewise regardless of formality, schedules, or interaction outside the classroom). This is to ensure that blended learning remains a combination of a form of traditional learning and a form of e-learning that are designed to complement each other and promote learning and application-learned behavior (Singh, 2003). Student satisfaction is therefore, a key factor in the success of blended learning programs. Student satisfaction results from a combination of factors, and in this study a model is proposed by aggregation of these factors into six groups: instructor, technology, class management, interaction, instruction, and learning management system.

The blended learning environment integrates the advantages of e-learning with some advantageous aspects of the traditional method, such as face-to-face interaction (Finn \& Bucceri, 2006). Its goal is to provide the most efficient and effective instruction experience by combining delivery modalities (Sen, 2011). Blended learning is described by Thorne (2003) as "a way of meeting the challenges of tailoring learning and development to the needs of individuals by integrating the innovative and technological advances offered by online learning with the interaction and participation offered in the best of traditional learning." Blended learning provides a flexible platform which helps in addressing the diversity seen in students' learning styles and needs via the integration of interactive online techniques with more traditional teaching strategies (Garrison \& Kanuka, 2004; Holley \& Dobson, 2008).

Blended learning systems change the way learners learn (Graham, 2006), but also change the way the teachers teach. This process of transformation cannot happen overnight and is expected to last 
for some time, but we hope that it will bring alongside also some quality changes in organization, planning and management of higher education (Žuvic-Butorac, Roncevic, Nemcanin, \& Nebic, 2011).

In her study of blended learning in Saudi Universities that operate in a gender-segregated environment, Alebaikan (2010) found that blended learning had the potential to enhance the quality of learning. Traditional instruction via live circuit TV for female students taught by male lecturers would be better supported by online tools, including discussions and course announcements. Thus, the advantage of facilitating interaction between lecturers and students would be more effective in blended courses taught by male lecturers in this segregated environment. This finding is similar to Albalawi (2007) findings that Saudi lecturers believe that web-based instruction will enhance teaching in the gender segregated Saudi Higher Education system.

\section{Student Satisfaction}

In the review of literature for this paper, it was noted that few studies on student satisfaction define satisfaction in blended learning. The Sloan Consortium defines student satisfaction as, "Students are successful in the learning and are pleased with their experience" (J. C. Moore, 2009). A similar definition is given by Sweeney and Ingram (2001). They define satisfaction as, "the perception of enjoyment and accomplishment in the learning environment." Both definitions focus on accomplishment and success in learning, and pleasure and enjoyment with the experience. Thurmond, Wambach, Connors, and Frey (2002) describe student satisfaction as "a concept that reflects outcomes and reciprocity that occur between students and an instructor." Reporting on satisfaction in a blended learning environment, $\mathrm{Wu}$, Tennyson, and Hsia (2010) define satisfaction as the sum of student feeling and attitude that results from aggregating all the benefits that a student hopes to receive from blended learning environment system.

Students spend considerable time and money, as well as exerting substantial effort in obtaining a quality education and should perceive their post-secondary educational experiences as being of high value (Knox, Lindsay, \& Kolb, 1993). Student satisfaction is important because it influences the student's level of motivation (Chute, Thompson, \& Hancock, 1999; Donahue \& Wong, 1997), which is an important psychological factor in student success (American Psychological Association, 1997). Meeting and exceeding the students' expectation not only satisfies students but also lead them to become advocates who provide a free promotion source for the university.

Sinclaire (2011) reported three compelling reasons for interest in student satisfaction. First, the Sloan Consortium's "Five Pillars of Quality Online Education" declares student satisfaction to be the most important key to continuing learning. It reflects learners' evaluation of the quality of all aspects of the educational program (Sloan, 2011). And there is evidence that student satisfaction is positively related to retention and a decision to take one or more additional courses (Booker \& Rebman, 2005). Lastly, student satisfaction is important because satisfied students represent a public relations asset for a college or university. If students are viewed as customers of college education, their satisfaction is important to recruitment efforts. Therefore, there is a need for more understanding of factors that affect student satisfaction with blended learning.

\section{Factors Contributing to Student Satisfaction in Blended Learning}

Several factors influence student satisfaction in the blended-learning environment. Bollinger and Martindale (2004) have identified three key factors central to student satisfaction: instructor, technology, and interactivity. Other factors, such as course management issues and instruction, which also contribute toward students' satisfaction, are discussed in this paper. 


\section{Instructor}

The instructor is the main predictor in course satisfaction (Finaly-Neumann, 1994; Williams \& Ceci, 1997). Student satisfaction is highly correlated with the performance of the instructor, particularly with his or her availability and response time (DeBourgh, 1999; Hiltz, 1993). Instructors must be available for consultation with students and, in addition, must be flexible in teaching that is time and plan independent (M. G. Moore \& Kearsley, 1996). The instructor not only becomes a facilitator of learning but also a motivator for the student. The instructor's feedback is the most important factor in satisfaction with instruction (Finaly-Neumann, 1994). To keep learners involved and motivated, feedback on assignments must be given in a timely manner (Smith \& Dillon, 1999). Communication must be on a regular basis (Mood, 1995) so as to prevent high levels of frustration among students (Hara \& Kling, 2003).

\section{Technology}

Technologies used in online and blended learning situations have the potential to enrich the learning experience, to do more than what can be done in face-to-face or other approaches (Smart \& Cappel, 2006). Access to technology is one of the most important factors influencing student satisfaction (Belanger \& Jordan, 2000). Students must have access to reliable equipment (Bower \& Kamata, 2000). Students with limited access are at a considerable disadvantage to learners who have unlimited access (Wegerif, 1998). Access is one of the most important factors influencing student satisfaction (Bower \& Kamata, 2000). Online learners must be familiar with the technology used in the course in order to be successful (Belanger \& Jordan, 2000). Students frustrated with technology in the course experience lower satisfaction levels (Chong, 1998; Hara \& Kling, 2003). Also, students without adequate technical support have also experienced high levels of frustrations in the online environment (Hara \& Kling, 2003).

\section{Course Management}

M. G. Moore and Kearsley (1996) point out that administrative support is of significant importance for online learning students. Access to other resources, such as course textbooks, libraries, technical support, and a help-desk number, are also important in blended learning.

\section{Interactivity}

Learning environments in which social interaction and collaboration are allowed and encouraged lead to positive learning outcomes (American Psychological Association, 1997). Collaborative learning tools can improve student satisfaction in the online learning environment (Bonk \& Cunningham, 1998; Gunawardena \& Zittle, 1998). These tools allow for group work and immediate feedback. Students are able to share viewpoints and discuss them with one another in a virtual environment, thereby gaining insights and perspectives. This type of environment allows for social interaction and creates meaningful, active, learning experiences (Bonk \& Cunningham, 1998).

\section{Instruction}

Student satisfaction is linked to student performance and positively associated with program completion rates and grade achievements (GPA). Expected grades by students positively affect their levels of satisfaction (Bower \& Kamata, 2000). Satisfied students learn more easily, are less likely to drop out of class, and are more likely to take additional blended learning courses and to recommend the course to others. The degree of student satisfaction and the likelihood of subsequent enrollment in online courses depend, in part, on how well courses are planned and taught (DeBourgh, 2003). A study by Carmel and Gold (2007) suggests that students who choose to en- 
roll in courses in an on-site format have the same rates of satisfaction and enrollment retention as do students that enroll in hybrid courses. The individual student's choice of instruction mode made no difference in grade outcome. Students enrolled in both forms of instruction seem to do well academically, and a decision with regard to persisting in their course of studies is not influenced by their GPA.

Other studies reported that student satisfaction level was related to the following:

\section{Courses}

Smart and Cappel (2006) reported that students in the elective course consistently rated the use of the online learning components more favorably than those in the required course. The elective class had more 4th-year students than the required classes; the 4th-year students rated several of the dimensions higher than the 2nd- and 3rd-year students. The higher ratings by the 4th-year students may suggest that they had more technological experience than the younger students and that they were more independent learners.

\section{Culture}

There is a strong link between culture and learning that is reflected in how people prefer to learn and how they tend to process information (Samovar, Porter, \& McDaniel, 2009). Culture plays a major role in shaping our social realities and learning experiences. Religion and culture in Saudi Arabia not only shape people's attitudes, practices, and behavior, but also shape the construction of their reality about their lives. Similarly, the social environment, in the case of online learning being integrated with face-to-face learning, is also exerting some influence on students' perceptions (Alebaikan \& Troudi, 2010).

\section{Student Age and the Number of Previous Distance Courses that They Had Taken}

So (2009) reported that student satisfaction levels related to individual characteristics were tested. Correlation analyses revealed that student satisfaction was positively related to age $(r=.32$, $\mathrm{p}<.05)$. This finding may indicate that older students were more satisfied with the course than younger students.

\section{Demographic Factor}

Melton, Graf, and Chopak-Foss (2009) found significant differences in class satisfaction between the blended learning section and the traditional sections, with blended learners reporting a higher level of class satisfaction. The blended learning design focused on active learning in the classroom portion of the course; the students might have rated higher satisfaction due to the enjoyment of the in-class portion and not necessarily the blended design. Additionally, overall quality educational satisfaction totals were compared by demographics, and lists only the demographics in which students were significantly more satisfied with the blended course. Demographic groupings that reported no difference in satisfaction between the different course structures included females, classifications of sophomores and above, 20 year old and above, and minority students. Students that were significantly more satisfied with the blended course included males, freshman, 18-19 year olds, and Caucasians.

\section{Gender}

Askar, Altun, and Ilgaz (2008) reported no statistically significant differences were found between females and males with respect to the satisfaction on blended learning; however female scores were statistically higher than the males for the face to face environment. Similar finding 
were reported by Adas and Abu Samais, (2011) with no significant differences in terms of gender even though the highest means were in favor of the females. However, Al-Fadhli (2008) reported a strong significance in students' attitudes toward e-learning in accordance with their gender. Female students' mean scores outscored their male counterparts in all areas (items). Female students were obviously positive in evaluating the e-learning elements of the course. Other researchers contended that males liked the Blended Learning component more than the females (Koohang, 2004).

\section{Purpose of the Study}

The purpose of this study is to

1. develop a valid instrument for measuring student satisfaction with blended learning;

2. identify and confirm factors influencing student satisfaction;

3. evaluate the level of students' satisfaction in each of the confirmed factors in the section above;

4. evaluate the level of the overall students' satisfaction with blended learning; and

5. explore whether satisfaction differs according to course and gender.

\section{Significance of the Study}

Universities operating in highly competitive markets need to find cost effective ways of delivering high quality education. The results of this study will provide blended learning instructors, administrators, educators, and other concerned parties with data regarding course satisfaction of university students toward blended learning. Student satisfaction is important and needs to be continuously assessed to assure quality of blended education experiences for students. The finding of this study will help assist the educator in developing strategies that extend the quality assurance framework to support the blended learning approach.

Satisfied students are more motivated and committed to their classes and, ultimately, are better learners than their dissatisfied counterparts (Biner, Dean \& Mellinger, 1994). Research on student satisfaction with blended learning is essential to ensure high quality learning can be achieved when instructor and students are physically separate.

\section{Methodology}

\section{Sample}

The sample of 153 students used in the study was drawn from the pool of undergraduate students enrolled in blended learning courses offered in the Fall Semester 2010 by the College of Information Technology. Of the 153 participants, a total of 108 completed the survey form $(70 \%)$. Seventy $(65 \%)$ were female and thirty eight $(35 \%)$ male.

\section{Instrument}

Participants completed a Student Satisfaction Survey Form (SSSF) which had three sections. The first section collected demographical/personal data while the second consisted of 35 items on a 5point Likert scale, ranging from ' 1 -strongly disagree' to '5-strongly agree' for positive items and from '1-strongly agree' to '5-strongly disagree' for negative items. The items were based on the outcome of the literature review, addressing elements integral to student satisfaction in blended learning environments. Out of these, 35 items addressed the following student satisfaction ele- 
ments: 1) instructor, 2) technology, 3) class management, 4) interaction, and 5) instruction (see Table 1). The third section included two open-ended questions.

\section{Table 1: Student Satisfaction Survey Form (SSSF)}

\begin{tabular}{|c|c|c|}
\hline Group & No. & Item \\
\hline \multirow{9}{*}{ Interaction } & I1 & A blended learning session keeps me always alert and focused. \\
\hline & $\mathrm{I} 2$ & $\begin{array}{l}\text { Interaction is adequately maintained with the lecturer when he/she is on the other side } \\
\text { of the blended learning classroom. }\end{array}$ \\
\hline & $\mathrm{I} 3$ & $\begin{array}{l}\text { Having students from the opposite gender on the other side of the blended learning } \\
\text { classroom listening to what I say might restrict my participation. }\end{array}$ \\
\hline & I4 & $\begin{array}{l}\text { A blended learning course makes it more important for students to visit the lecturer } \\
\text { during office-hours. }\end{array}$ \\
\hline & I5 & $\begin{array}{l}\text { I cannot interrupt the lecturer to ask a question when he/she is on the other side of the } \\
\text { blended learning classroom. }\end{array}$ \\
\hline & I6 & I am satisfied with the quality of interaction between all involved parties. \\
\hline & I9 & I am dissatisfied with the process of collaboration activities during the course. \\
\hline & $\mathrm{I} 10$ & I am satisfied with the way I interact with other students. \\
\hline & I1 1 & I am satisfied with my participation in the class. \\
\hline \multirow{12}{*}{ Instruction } & I19 & $\begin{array}{l}\text { The use of blended learning technology in this course encourages me to learn inde- } \\
\text { pendently. }\end{array}$ \\
\hline & $\mathrm{I} 20$ & My understanding is improved compared to similar courses I studied before. \\
\hline & $\mathrm{I} 21$ & My performance in exams is improved compared to similar courses I studied before. \\
\hline & $\mathrm{I} 22$ & I am satisfied with the level of effort this course required. \\
\hline & $\mathrm{I} 23$ & I am dissatisfied with my performance in this course. \\
\hline & $\mathrm{I} 24$ & I believe I will be satisfied with my final grade in the course. \\
\hline & $\mathrm{I} 25$ & I am satisfied with how I am able to apply what I have learned in this course. \\
\hline & $\mathrm{I} 26$ & $\begin{array}{l}\text { If I had known this was going to be a blended learning class, I would not have taken } \\
\text { it. }\end{array}$ \\
\hline & $\mathrm{I} 27$ & I am willing to take another course using the blended learning delivery mode \\
\hline & $\mathrm{I} 28$ & I am satisfied enough with this course to recommend it to others. \\
\hline & $\mathrm{I} 29$ & $\begin{array}{l}\text { Compared to face-to-face course settings, I am less satisfied with this learning ex- } \\
\text { perience. }\end{array}$ \\
\hline & $\mathrm{I} 38$ & I enjoy working on assignments by myself. \\
\hline \multirow{5}{*}{ Instructor } & I7 & The instructor makes me feel that I am a true member of the class. \\
\hline & I8 & I am dissatisfied with the accessibility and availability of the instructor. \\
\hline & $\mathrm{I} 16$ & The instructor uses blended learning technology appropriately. \\
\hline & $\mathrm{I} 32$ & Class assignments were clearly communicated to me. \\
\hline & $\mathrm{I} 33$ & Feedback on evaluation of tests and other assignments was given in a timely manner. \\
\hline \multirow{3}{*}{$\begin{array}{c}\text { Course } \\
\text { Management }\end{array}$} & $\mathrm{I} 30$ & $\begin{array}{l}\text { Discipline is highly observed when the lecturer is on the other side of the blended } \\
\text { learning classroom. }\end{array}$ \\
\hline & $\mathrm{I} 31$ & The lecturer/supervisor always takes attendance. \\
\hline & $\mathrm{I} 39$ & I attend videoconferencing classes the same way I attend face-to-face classes. \\
\hline \multirow{6}{*}{ Technology } & $\mathrm{I} 12$ & The instructor's voice is audible. \\
\hline & $\mathrm{I} 13$ & Course content shown or displayed on the smart board is clear. \\
\hline & $\mathrm{I} 14$ & The microphone is in good working condition. \\
\hline & $\mathrm{I} 15$ & $\begin{array}{l}\text { The video image is clear and comprehensive when the lecturer is on the other side of } \\
\text { the blended learning classroom. }\end{array}$ \\
\hline & $\mathrm{I} 17$ & $\begin{array}{l}\text { Technical problems are not frequent and they do not adversely affect my understand- } \\
\text { ing of the course. }\end{array}$ \\
\hline & $\mathrm{I} 18$ & The technology used for blended teaching is reliable. \\
\hline
\end{tabular}




\section{Reliability}

In order to determine the internal reliability of the questionnaire, a reliability analysis was performed with the use of Cronbach's alpha after the completion of the data collection phase. The alpha reliability coefficient of the satisfaction scale was 0.91 , indicating that the instrument was highly reliable. The subscale reliability ranged from 'high' for the instruction dimension (.84) and the technology dimension (.80), to 'acceptable' for the interaction dimension (0.75) and the instructor dimension (0.70), to 'moderate' for course management (.57) dimension (see Table 2).

Table 2: Reliability of the Student Satisfaction Survey Form (SSSF)

\begin{tabular}{|l|c|c|c|c|c|c|}
\hline \multirow{2}{*}{ Group } & \multirow{2}{*}{$\begin{array}{c}\text { Number } \\
\text { of Items }\end{array}$} & Mean & SD & Cronbach's $\alpha$ & \multicolumn{2}{c|}{ v5\% Confidence Inter- } \\
\cline { 5 - 7 } & & & & & & \\
\hline Interaction & $\mathbf{9}$ & 3.1 & 1.24 & 0.75 & .65 & 0.80 \\
\hline Instruction & $\mathbf{1 2}$ & 3.0 & 1.23 & 0.84 & .667 & .814 \\
\hline Instructor & $\mathbf{5}$ & 3.8 & 1.18 & 0.70 & 0.59 & 0.78 \\
\hline $\begin{array}{l}\text { Course Manage- } \\
\text { ment }\end{array}$ & $\mathbf{3}$ & 3.6 & 1.35 & 0.57 & 0.40 & 0.694 \\
\hline Technology & $\mathbf{6}$ & 3.7 & 1.18 & 0.80 & 0.71 & 0.84 \\
\hline
\end{tabular}

\section{Results}

A t-test was conducted on the category of overall student satisfaction with blended learning courses, to evaluate whether the mean was significantly different from 2.5 - an accepted mean for student satisfaction (Giannousi, Vernadaki, Derri, Michalopoulos, \& Kioumourtzoglou, 2009). The sample grand mean of $3.3(\mathrm{SD}=.48)$ was higher than $2.5,(\mathrm{t}=43.2, \mathrm{df}=38, \mathrm{p}<0.05)$ for blended learning satisfaction. The $95 \%$ confidence interval for blended learning satisfaction mean ranged from 3.14 to 3.45 . The results show that student satisfaction is higher than the average.

\section{Satisfaction by Gender}

Table 3 shows the mean and standard deviation for student satisfaction of male students and female students who experienced blended learning courses. The data in Table 3 reflect a significant difference between male and female students. A t-test was to check the following hypothesis:

There is no significant difference in students' satisfaction between male and female students who experienced bended learning courses.

The result was $(t=50.19, \mathrm{df}=38, \mathrm{p}<.05)$. Thus, the hypothesis is rejected. Male students are more satisfied with blended learning than female students (see Table 3). This can be attributed to the following interrelated factors.

1. In some majors including Information Technology majors at AUST, female students maintain a higher AGPA average during their studies than their male counterparts.

2. Female students show more interest in their studies than their male counterparts.

3. In face-to-face classes female sections have more interaction and discussion with instructors.

4. In blended learning classes some female students do not ask questions because the male students are listening or because the instructor is not in the same room to motivate them.

This in turn affects their satisfaction level. 
Table 3: Mean and Standard Deviation for Students' Satisfaction by Gender

\begin{tabular}{|c|c|c|c|c|c|c|c|}
\hline \multicolumn{2}{|c|}{ Items } & \multirow{2}{*}{\multicolumn{2}{|c|}{ All Students }} & \multicolumn{4}{|c|}{ By Gender } \\
\hline \multirow{2}{*}{ No. } & \multirow{2}{*}{ mode } & & & \multicolumn{2}{|c|}{ Male } & \multicolumn{2}{|c|}{ Female } \\
\hline & & mean & SD & mean & SD & mean & SD \\
\hline I1 & 3 & 2.6 & 1.248 & 3.1 & 1.470 & 2.10 & 0.957 \\
\hline I2 & 3 & 3 & 1.266 & 3.6 & 1.426 & 2.4 & 0.972 \\
\hline I3 & 5 & 3.45 & 1.354 & 3.6 & 1.343 & 3.3 & 1.341 \\
\hline I4 & 4 & 3.45 & 1.263 & 3.5 & 1.191 & 3.4 & 1.284 \\
\hline I5 & 5 & 3.3 & 1.516 & 3.5 & 1.676 & 3.1 & 1.401 \\
\hline I6 & 3 & 3.1 & 1.171 & 3.6 & 1.300 & 2.6 & 0.959 \\
\hline I7 & 5 & 3.7 & 1.292 & 3.9 & 1.337 & 3.5 & 1.253 \\
\hline I8 & 3 & 3.0 & 1.364 & 3.3 & 1.543 & 2.9 & 1.236 \\
\hline I9 & 3 & 3.4 & 1.308 & 3.9 & 1.302 & 2.9 & 1.191 \\
\hline I10 & 3 & 3.6 & 1.131 & 4.0 & 1.066 & 3.2 & 1.070 \\
\hline I11 & 3 & 3.35 & 1.276 & 3.6 & 1.442 & 3.1 & 1.139 \\
\hline I12 & 5 & 3.75 & 1.276 & 4.3 & 1.024 & 3.2 & 1.136 \\
\hline I13 & 5 & 4.5 & 0.802 & 4.5 & .768 & 4.5 & .796 \\
\hline I14 & 5 & 3.6 & 1.307 & 4.0 & 1.129 & 3.2 & 1.313 \\
\hline I15 & 5 & 3.9 & 1.269 & 4.2 & 1.182 & 3.6 & 1.276 \\
\hline I16 & 5 & 4 & 0.935 & 4.4 & 0.944 & 3.6 & .896 \\
\hline I17 & 3 & 3.65 & 1.211 & 4.0 & 1.201 & 3.3 & 1.155 \\
\hline I18 & 3 & 3.6 & 1.106 & 4.0 & 1.000 & 3.2 & 1.079 \\
\hline I19 & 3 & 3.15 & 1.155 & 3.3 & 1.367 & 3.0 & 1.015 \\
\hline I20 & 3 & 2.7 & 1.143 & 2.9 & 1.385 & 2.5 & .947 \\
\hline I21 & 3 & 2.7 & 1.183 & 2.9 & 1.437 & 2.5 & 1.023 \\
\hline I22 & 3 & 3.2 & 1.150 & 3.2 & 1.356 & 3.2 & 1.51 \\
\hline I23 & 3 & 3 & 1.307 & 3.1 & 1.401 & 2.9 & 1.278 \\
\hline I24 & 3 & 3.4 & 1.080 & 3.7 & 1.029 & 3.1 & 1.073 \\
\hline I25 & 3 & 3.4 & 1.179 & 3.6 & 1.346 & 3.2 & 1.084 \\
\hline I26 & 3 & 3 & 1.329 & 3.4 & 1.399 & 2.6 & 1.208 \\
\hline I27 & 1 & 2.55 & 1.288 & 3.1 & 1.490 & 2.0 & $\begin{array}{l}.954 \\
\end{array}$ \\
\hline I28 & 3 & 2.9 & 1.259 & 3.2 & 1.391 & 2.6 & 1.119 \\
\hline I29 & 1 & 2.5 & 1.367 & 2.7 & 1.637 & 2.3 & 1.208 \\
\hline I30 & 3 & 2.95 & 1.319 & 2.8 & 1.391 & 3.1 & 1.254 \\
\hline I31 & 5 & 4 & 1.394 & 4.0 & 1.255 & 4.0 & 1.448 \\
\hline I32 & 5 & 3.7 & 1.222 & 3.8 & 1.101 & 3.6 & 1.267 \\
\hline I33 & 3 & 3.7 & 1.274 & 3.8 & 1.377 & 3.6 & 1.180 \\
\hline I38 & 5 & 3.55 & 1.293 & 3.7 & 1.411 & 3.4 & 1.240 \\
\hline I39 & 5 & 3.85 & 1.389 & 4.2 & 1.126 & 3.5 & 1.461 \\
\hline
\end{tabular}

\section{Student Satisfaction Factor Analysis}

\section{Interaction Related Factors}

The overall mean for student satisfaction in this factor was 3.1. The item (I10) related to interaction with other students having the highest mean, 3.6 (4.0 for men and 3.2 for women). This suggests that students are satisfied with the level of interaction between themselves. The item (I1) with the lowest score in this group was, "A blended learning session keep me always alert and focused." The low score 2.6 is understandable ( 3.1 for men and 2.1 for women) because there may be less discipline and more interruption among students when the lecturer is in the remote classroom. Moreover, women show that they are less satisfied in item (I2) than their counterparts (3.6 for men and 2.4 for women). To find out why some women students cannot interact freely 
with their instructor, a new questionnaire was distributed to a sample of 80 women students who studied blended learning courses. Seventy one women students responded to the questionnaire $(88.7 \%)$. Thirty six (50.8\%) women students answered yes to the question, "Do you interact with your instructor when he/she is on the other side of the VC classroom?" Thirty five (49.2\%) answered no. When asked to give reasons twenty one women students (29.5\%) answered, "I don't engage in enough concentration to enable me to participate when the instructor is on the other side of the VC classroom." Fourteen women students (19.7\%) answered, "I don't feel comfortable when I know that men students are listening to what I am saying."

\section{Technology Related Factors}

Most students are satisfied with the technology used in the videoconferencing component of blended learning (mean=3.7). The item related to the overall reliability of technology has the mean $=3.6$, which is high .

\section{Instructor Related Factors}

Students in general were satisfied with instructors; the highest satisfaction in this group showed mean=3.8. All items in this group had a mean greater than or equal to 3.6, which is also high.

\section{Course Management Related Factors}

The results showed that students are generally satisfied with class management (mean=3.6). The lowest mean item was related to discipline in the video-conferencing classroom (mean $=2.95$.) which, although good, requires improvement.

\section{Instruction Related Factors}

The average mean for student satisfaction in this group was 3.0, but there were also some areas in which the students were less satisfied. When asked whether they were willing to take another course in blended learning most students disagreed with mean=2.5 (3.1 for men, 2.0 for women). When asked whether they are happy with their performance, they showed higher satisfaction with mean $=3.0$ (3.1 for men and 2.9 for women). When asked about satisfaction with their grade they showed higher satisfaction with mean $=3.4$ ( 3.7 for men and 3.1 for women). The results suggest that students of both genders prefer face-to-face learning, even if their performance and grades with blended learning are similar.

\section{Limitations}

This study focused on undergraduate students in the College of Information Technology, at AUST taking blended learning courses. While valid, the results should not be overgeneralized by the reader when applied to other colleges or other institutions. In addition, the study used a selfreported questionnaire survey form which is limited in nature by the accuracy of the participant's response (Kerlinger \& Lee, 2000). Although the researchers took steps to facilitate accurate reporting, such as confidentiality and voluntary participation, these procedures might have not ruled out the bias associated with self-reported data, including social desirability. Despite the limitation of the instrument used, including socially desirable answers, a self-report data is a strong method to measure the level of students' satisfaction.

\section{Conclusion}

Student satisfaction in blended learning is important because it can impact motivation and, therefore, student success and completion rates. Measurement of satisfaction is also valuable to institutions because it can be used to evaluate courses and programs and, to a certain degree, to predict 
student attrition rates. In this research, analysis of data from survey forms has suggested that while blended learning continues to be regarded by most students as less effective, students still preferred face-to-face courses even though they were satisfied with their grades and performance in blended learning courses. Male students tended to be more satisfied with blended learning than their female counterparts.

\section{Future Study}

Further research is needed to find the reasons behind the varying levels of satisfaction in these areas so as to aid understanding of the components of student satisfaction and facilitate improvements in the quality of blended learning courses offered. Being able to understand the needs of students, to support students in blended learning courses, and to promote a successful learning experience will be critical to the overall success of blended learning in the college. However, in order to do so, a larger sample will be required, which should include face-to-face and blended learning courses. This would also help to determine the reason for differences in satisfaction based on course, instructor, gender, or personality, and suggest recommendations for improving overall learning outcomes. Research should also be extended to include the investigation of instructor satisfaction and the relationship between student and instructor satisfaction. Further research is also needed to assess the difference in student satisfaction between blended learning and face-to-face learning via the comparison of blended learning courses with the same courses offered by the face-to-face method.

The study can also be extended to include students of other colleges at the university.

\section{References}

Adas, D., \& Abu Shmais, W. (2011). Students' perceptions towards blended learning environment using the OCC. An-Najah University Journal for Research - Humanities, 25(6), 1681-1710.

Albalawi, M. S. (2007). Critical factors related to the implementation of web-based instruction by highereducation faculty at three universities in the Kingdom of Saudi Arabia. Unpublished dissertation of Doctor of Education. The University of West Florida.

Alebaikan, R., (2010). Perceptions of blended learning in Saudi universities. Doctor of Philosophy Thesis, University of Exeter.

Alebaikan, R. \& Troudi, S. (2010). Online discussion in blended courses at Saudi universities. Procedia Social and Behavioral Sciences, 2(2), 507-514.

Al-Fadhli, S. (2008). Students' perceptions of e-learning in Arab society: Kuwait University as a case study. E-Learning and Digital Media, 5(4), 418-428. Available at http://dx.doi.org/10.2304/elea.2008.5.4.418

Al-Yousef, N. (2009). The status of women in the Arab gulf countries. Retrieved from http://faculty.ksu.edu.sa/NourahAlyousef/Publications/Women\%20in\%20the\%20Gulf.pdf

American Psychological Association. (1997). Learner-centered psychological principles: A framework for school redesign and reform. Washington, DC.

Askar, P., Altun, A., \& Ilgaz, H. (2008). Learner satisfaction on blended learning. E-leader conference, Krakow, Poland

Belanger, F., \& Jordan, D. H. (2000). Evaluation and implementation of distance learning: Technologies, tools and techniques. Hershey, PA: Idea Publishing Group.

Biner, P. M., Dean, R. S., \& Mellinger, A. E. (1994). Factors underlying distance learner satisfaction with televised college-level courses. The American Journal of Distance Education, 8(1), 60-71. 
Bollinger, D. U.. \& Martindale, T. (2004). Key factors for determining student satisfaction in online courses. International Journal of E-Learning, (3)1, 61-67.

Bonk, C. J., \& Cunningham, D. J. (1998). Searching for learner-centered, constructivist, and socio-cultural components of collaborative educational learning tools. In C. J. Bonk \& K. S. King (Eds.), Electronic collaborators: Learner-centered technologies for literacy, apprenticeship, and discourse (pp. 25-50). Mahwah, NJ: Lawrence Erlbaum Associates.

Booker, Q. E., \& Rebman, C. E. (2005). E-student retention: Factors affecting customer loyalty for online program success. Issues in Information Systems, 1(1), 183-189.

Bower, B. L., \& Kamata, A. (2000). Factors influencing student satisfaction with online courses. Academic Exchange Quarterly, 4(3), 52-56.

Carmel, A., \& Gold, S. (2007). The effects of course delivery modality on student satisfaction and retention and GPA in on-site vs. hybrid courses. Turkish Online Journal of Distance Education-TOJDE, 8(2: Article 11), 127-135.

Chong, S. M. (1998). Models of asynchronous computer conferencing for collaborative learning in large college classes. In C. J. Bonk \& K. S. King (Eds.), Electronic collaborators: Learner-centered technologies for literacy, apprenticeship, and discourse (pp. 157-182). Mahwah, NJ: Lawrence Erlbaum Associates.

Chute, A. G., Thompson, M. M., \& Hancock, B. W. (1999). The McGraw-Hill handbook of distance learning. New York: McGraw-Hill.

Culture of United Arab Emirates. (n.d.). Retrieved from http://www.everyculture.com/To-Z/United-ArabEmirates.html\#b

DeBourgh, G. A. (1999). Technology is the tool, teaching is the task: Student satisfaction in distance learning. Proceedings of Society for Information Technology \& Teacher Education International Conference 1999, San Antonio, TX, (pp. 131-137).

DeBourgh, G. A. (2003). Predictors of student satisfaction in distance-delivered graduate nursing courses: What matters most? Journal of Professional Nursing, 19(3), 149-163.

Donahue, T. L., \& Wong, E. H. (1997). Achievement motivation and college satisfaction in traditional and nontraditional students. Education, 118, 237-243.

Finaly-Neumann, E. (1994). Course work characteristics and students' satisfaction with instructions. Journal of Instructional Psychology, 21(2), 14-19.

Finn, A. \& Bucceri, M. (2006). A case study approach to blended learning. Los Angeles: Centra Software.

Garrison, D. R., \& Kanuka, H. (2004). Blended learning: Uncovering its transformative potential in higher education. The Internet and Higher Education, 7(2), 95-105.

Giannousi, M., Vernadakis, N., Derri, V., Michalopoulos, M., \& Kioumourtzoglou, E. (2009). Students' satisfaction from blended learning instruction. Proceedings of the TCC Worldwide Online Conference, 1, 61-68.

Graham, C. R. (2006). Blended learning systems. In C. J. Bonk \& C. R. Graham, The handbook of blended learning: Global perspectives, local designs. Pfeiffer.

Gunawardena, C. N., \& Zittle, R. H. (1998). Faculty development programmes in distance education in American higher education. In C. Latchem \& F. Lockwood (Eds.), Staff development in open and flexible learning (pp. 105-114). New York: Routledge.

Hara, N., \& Kling, R. (2003). Students' distress with a Web-based distance education course: An ethnographic study of participants' experiences. Turkish Online Journal of Distance Education-TOJDE, 4(1), 1-30.

Hiltz, S. R. (1993). Correlates of learning in a virtual classroom. International Journal of Man-Machine Studies, 39, 71-98. 
Holley, D., \& Dobson, C. (2008). Encouraging student engagement in a blended learning environment: The use of contemporary learning spaces. Learning, Media and Technology, 33(2), 139-150.

Kerlinger, F. N., \& Lee, H. P. (2000). Foundation of behavioral research $\left(4^{\text {th }}\right.$ ed.). Forth Worth, TX: Harcourt.

Kim, W. (2007). Towards a definition and methodology for blended learning. Workshop on Blended Learning, 2007, Edinburgh, United Kingdom, Proceedings, 1-8.

Knox, W. E., Lindsay, P., \& Kolb, M. N. (1993). Does college make a difference? Long-term changes in activities and attitudes. Westport, CT: Greenwood Press.

Koohang, A. (2004). Students' perceptions toward the use of the digital library in weekly web-based distance learning assignments portion of a hybrid programme. British Journal of Educational Technology, 35, 617-626.

Melton, B., Graf, H., \& Chopak-Foss, J. (2009). Achievement and satisfaction in blended learning versus traditional general health course designs. International Journal for the Scholarship of Teaching and Learning, 3(1). Retrieved from http://www.georgiasouthern.edu/ijsotl

Ministry of Higher education, Commission for Academic Accreditation (CAA) annual report, (2011). Available at https://www.caa.ae/caa/images/AnnualReport2011.pdf

Mood, T. A. (1995). Distance education: An annotated bibliography. Englewood, CO: Libraries Unlimited, Inc.

Moore, J. C. (2009). A synthesis of Sloan-C effective practices: December 2009. Journal of Asynchronous Learning Networks, 13(4), 84-94. Retrieved from http://sloanconsortium.org/publications/freedownloads

Moore, M. G., \& Kearsley, G. (1996). Distance education: A systems view. Belmont, CA: Wadsworth Publishing Company.

Samover, L.A., Porter, R. E., \& McDaniel, E. R. (2009). Communication between cultures. Boston: Wadsworth.

Sen, T. (2011). Application of blended and traditional class teaching approach in higher education and the student learning experience. International Journal of Innovation, Management and Technology, 2(2), 107-109.

Sinclaire, J. (2011). Student satisfaction with online learning: Lessons from organizational behavior. Research in Higher Education Journal, 11, 1-18.

Singh, H. (2003). Building effective blended learning programs. Educational Technology, 43(6), 51-54.

Sloan. (2011). The 5 Pillars of Quality Online Education. The Sloan Consortium. Retrieved from http://sloanconsortium.org/5pillars

Smart, K. L., \& Cappel, J. J. (2006). Students' perceptions of online learning: A comparative study. Journal of Information Technology Education, 5, 201-219. Retrieved from http://www.jite.org/documents/Vol5/v5p201-219Smart54.pdf

Smith, P. L., \& Dillon, C. L. (1999). Comparing distance learning and classroom learning: Conceptual considerations. The American Journal of Distance Education, 13(2), 6-23.

So, H. J. (2009). Is blended learning a viable option in public health education? A case study of student satisfaction with a blended graduate course. Journal of Public Health Management \& Practice, 15(1), 59- 66.

Sweeney, J. C., \& Ingram, D. (2001). A comparison of traditional and web--based tutorials in marketing education: An exploratory study. Journal of Marketing Education, 23(1), 55-62.

Thorne, K. (2003). Blended learning: How to integrate online and traditional learning. London: Kogan Page. 
Thurmond, V. A., Wambach, K., Connors, H. R., \& Frey, B. B. (2002). Evaluation of student satisfaction: Determining the impact of a web-based environment by controlling for student characteristics. The American Journal of Distance Education, 16(3), 169-189.

UAE Constitution. (n.d.). Retrieved from http://www.mfnca.gov.ae/?lang=en\&m=options\&act=content detail\&content id=438

UAE, The official Website. (2012). Retrieved from http://www.uaeinteract.com/education/

Weber, A. S. (2010). Web-based learning in Qatar and the GCC states. Center for International and Regional Studies, Georgetown University School of Foreign Service in Qatar, Occasional Paper No. 5.

Wegerif, R. (1998). The social dimensions of asynchronous learning networks. Journal of Asynchronous Learning Networks, 2(1), 34-39.

Williams, W. M., \& Ceci, S. J. (1997). 'How'm I doing?' Problems with student ratings of instructors and courses. Change, 29, 12-23.

Women in the United Arab Emirates: A Portrait of Progress. (2008). Retrieved from http://lib.ohchr.org/HRBodies/UPR/Documents/Session3/AE/UPR_UAE_ANNEX3_E.pdf

Women in the UAE. (2012). UAE Vice President, Prime minister, and Ruler of Dubai His Highness Sheikh Mohammed Bin Rashid Al Maktoum Website. Retrieved from http://www.sheikhmohammed.ae/vgnext-templating/v/index.jsp?vgnextoid=7d3c4c8631cb4110VgnVCM100000b0140a0aRCRD

Wu, H., Tennyson, R. D., \& Hsia, T. (2010). A study of student satisfaction in a blended e-learning system environment. Computers and Education, 55, 155-164.

Žuvic-Butorac, M., Roncevic, N., Nemcanin, D., \& Nebic, Z. (2011). Blended e-learning in higher education: Research on students' perspective. Issues in Informing Science and Information Technology, 8, 409-429.

\section{Biographies}

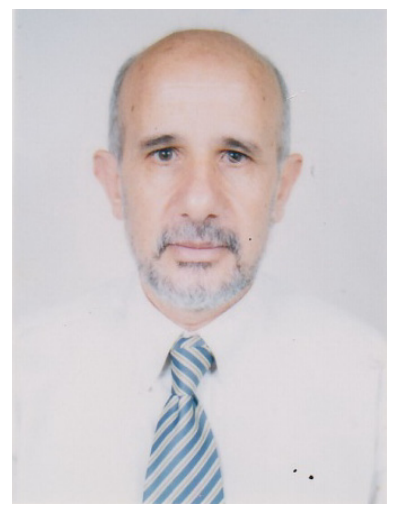

Mahmoud Abou Naaj, Ph.D. is Associate Professor of Information Technology at Ajman University of Science and Technology (AUST). He has obtained his Ph.D. in Computer Science at the University of Leeds (UK). Currently, he is the dean of the College of University Requirements and Academic Counseling. He served as the dean of the College of Information Technology and dean of Admission and Registration at AUST. His current research interests include IT Education, Blended Learning, Assessments, and Computer Algorithms. 


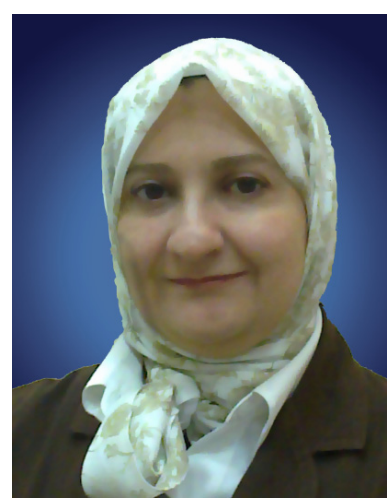

Mirna Nachouki, Ph.D. is an assistant professor of Information Technology at Ajman University of Science and Technology (AUST). She received her Ph.D. from University of Paul Sabatier, Toulouse, France. Currently, she is the Head of Information Systems Department. Her research interests include blended learning, IT education, curriculum design and development, databases and data mining. Her current teaching specialties comprise programming, data structures and databases.

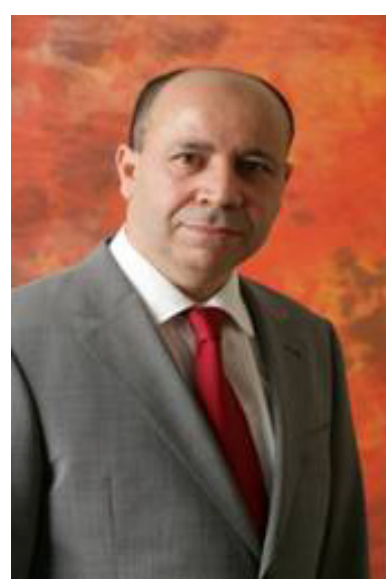

Ahmed ANKIT, Ph.D. is associate Professor of Applied Linguistics at Ajman University of Science and Technology (AUST). He holds a Master and Ph.D. from the School of Foreign Languages at the University of Salford, UK. He has been working on the e-learning project in AUST, since 2006. His research field S of interest are Discourse Analysis, Education Technology and Communication.

ankit@ajman.ac.ae 